\title{
ANAEROBIC BIOPROCESSING OF LOW RANK COALS
}

CONTRACT NO. DE-AE22-90PC90051

PROGRESS REPORT

July 1 - September 30, 1991

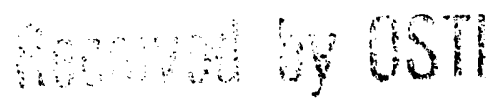

NOV 201991

\author{
Mahendra K. Jain \\ Ramani Narayan \\ Ohantaek Han
}

\section{DISCLAIMER}

\begin{abstract}
This report was prepared as an account of work sponsored by an agency of the United States Government. Neither the United States Government nor any agency thereof, nor any of their employees, makes any warranty, express or implied, or assumes any legal liability or responsibility for the accuracy, completeness, or usefulness of any information, apparatus, product, or process disclosed, or represents that its use would not infringe privately owned rights. Reference herein to any specific commercial product, process, or service by trade name, trademark, manufacturer, or otherwise does not necessarily constitute or imply its endorsement, recommendation, or favoring by the United States Government or any agency thereof. The views and opinions of authors expressed herein do not necessarily state or reflect those of the United States Government or any agency thereof.
\end{abstract}

\section{Michigan Biotechnolog.y Institute \\ 3900 Collins Road \\ P.O. Box 27609 \\ Lansing, Michigan 48909}




\title{
QUARTERLY PROGRESS REPORT
}

\author{
Anaerobic Bioprocessing of Low: Rank Coals \\ Report Period: July 1 - September 30, 1991 \\ Contract No. DE-AE22-90PC90051
}

\section{INTRODUCTION}

The overall goal of this project is to find biological methods to remove carboxylic functionalities from low rank coals under ambient conditions and to assess the properties of these modified coals towards coal liquefaction. The main objectives for this quarter were: (i) enrichment of anaerobic microbial consortia in a coal fed chemostat, (ii) characterization of biocoal products and examination of liquefaction potential, (iii) isolation of decarboxylating organisms and evaluation of the isolated organisms for decarboxylation. The project began on September 12, 1990.

\section{PROGRESS REPORT}

\section{Coal Decarboxylation by Adapted Microbial Consortia under Batch Reactor Configuration}

1. Coal Decarboxylation by Adapted Microbial Consortia in the Batch Fermentor System.

It was evident from previous experiments that periodic withdrawal of homogeneous uniform coal samples from batch reactors was difficult mainly due to insoluble nature of coal, attachment of coal to glass vessel, tubings, heater, and $\mathrm{pH}$ probes and possible separation of coal as a result of differences in the density due to particle size. Thus, the results obtained from such samples were likely to vary and lead to erroneous conclusions. Therefore, two batch systems were set up to examine if the periodic sampling could be a cause for variations in results. Samples were to be withdrawn every week from one fermentor (\#5) while another (\#6) was to be operated undisturbed. Experiment was conducted as described in earlier reports. At the end of about seven weeks the results (Figures 1 and 2) indicated that $20 \%$ more gas was produced from the undisturbed fermentor. This difference, however, could be explained on the basis of withdrawal of about $48 \mathrm{ml}$ sample of broth containing coal. Methane was detected in small amounts $(<0.01 \%)$ in the exit gas of both the fermentors. Changes in coal were studied by CHN and thermogravimetric analysis.

2. Continual enrichment/adaptation of microbial consortia at small scale in vials.

Significant efforts were put to maintain anaerobic microbial consortia having potentid decarboxylating activity. Microbial consortia obtained from anaerobic tubes, vials or fermentors are being subcultured at about 3-4 week interval. However, it was noticed that if the consortium is maintained just on coal as carbon source, it's decarboxylating activity is significantly reduced 
(Table 1). This indicates the possible selection of non-decarboxylators over decarboxylators either due to differences in growth rates or due to other obligate requirement for decarboxylation. Thus, microbial consortia maintained on various carbon sources were examined for coal decarboxylation (this term is used here loosely since production of $\mathrm{CO}_{2}$ from coal is taken as an indication of its decarboxylation). The results presented in Table 2 indicates that there was a large amount of net $\mathrm{CO}_{2}$ and $\mathrm{CH}_{4}$ production when this microbial consortium was maintained on various substrates as compared to when it was maintained on coal. Biotreated coal was stored as freeze dried for chemical characterization later.

3. Effect of inhibition of methanogenesis and high $\mathrm{CO}_{2}$ partial pressure on coal decarboxylation.

Since the microbial consortia contains methanogens, $\mathrm{CH}_{4}$ was always produced possibly from $\mathrm{CO}_{2}$. It is, therefore, not simple to determine the exact amount of $\mathrm{CO}_{2}$ produced from coal since part of $\mathrm{CO}_{2}$ is converted to methane. Bromoethane sulfonate (BES) has been widely used to inhibit methane production. In the experiments conducted in presence of BES, production of $\mathrm{CH}_{4}$ was completely inhibited but $\mathrm{CO}_{2}$ production was observed only for a week (Figure 3). This seems to indicate that either BES also affected the decurboxylation reaction or the coal decarboxylation takes place only initially after which $\mathrm{CH}_{4}$ and $\mathrm{CO}_{2}$ are produced from acetate which in turn is produced from some coal monomers. Thus, inhibition of methane production from acetate will also mean no additional $\mathrm{CO}_{2}$ production.

In order to exclude the possibility of feed back inhibition by the accumulated $\mathrm{CO}_{2}$ on decarboxylation, experiments were set up with higher partial pressure of $\mathrm{CO}_{2}$. The results indicate that high initial partial pressure of $\mathrm{CO}_{2}$ did inhibit net $\mathrm{CO}_{2}$ production but the results (Table 3 ) are not conclusive enough to prove any feed back inhibition.

4. Effect of removal of water-soluble compounds on coal decarboxylation

It is known that coals have water soluble compounds which may be inhibitory to microorganisms. In order to examine the effect of removal of such compounds on coal decarboxylation, two low-rank coals, North Dakota lignite and Wyodak subbituminous, were used after a wash. Non-washed coals were also used as controls. The results presented in Table 4 show higher gas production from washed coals than non-washed coals. Subbituminous coal seems to contain water soluble compounds which are more inhibitory than those present in lignite.

\section{Characterization of Biocoal Products and Examination of Liquefaction Potential}

The biotreated coal was analyzed for its carbon, hydiogen and nitrogen content. The thermogravimetric analysis was also performed to determine whether decarboxylation will have any impact on volatilization of coal. The results of $\mathrm{CHN}$ analysis presented in Table 5 indicate increase in $\mathrm{H} / \mathrm{C}$ ratio of coals that were biotreated in the fermentor. The coal samples obtained from tubes did not have high $\mathrm{H} / \mathrm{C}$ probably due to loss of coal hydrogen as $\mathrm{CH}_{4}$. Table 6 
exhibits \% increase in the ratio of volatile carbon to fixed carbon in the biotreated coal indicating that such coals may be better for liquefaction.

Isolation of Decarboxylating Organisms and Evaluation of the Isolated Organisms for Decarboxylation

Four potential isolates and one microbial consortium were evaluated for their coal decarboxylating ability in presence of supplemental carbon sources. The experiment was conducted in anaerobic tubes. Benzoate, lactate or succinate was used as supplemental carbon and energy source at $0.4 \%$. Based on the net $\mathrm{CO}_{2} / \mathrm{CH}_{4}$ production, results presented in Table 7 show succinate to be a better supplemental carbon source for jsolates $8, \mathrm{C} 3$ and A2, and lactate for isolates R623 and CON. Total gas production probably from coal was less than $4 \%$ with highesi gas production by culture numbers $8(3.89 \%)$ and $C 3(2.84 \%)$. Number 8 culture is a mixed culture consortium that contains methanogenic bacteria, thus, produces methane.

\section{SIGNIFICANT ACHIEVEMENTS}

1. Microbial consortia with good decarboxylating ability (production of $\mathrm{CO}_{2}$ ) obtained.

2. biotreated coals in comparison to starting coal have been demonstrated to have high $\mathrm{H} / \mathrm{C}$ ratio.

3. An increase in the ratio of volatile carbon to fixed carbon has been demonstrated in the batch biotreated coals.

\section{DIFFICULTIES/PROBLEMS}

1. Reproducibility of FT-IR analyses.

2. Variations in results due to coal processing conditions (aerobic versus anaerobic) after the anaerobic biotreatment of coal. 
Figure 1. The profile of carbon dioxide production from coal+succinate under batch fermentation conditions with periodic sampling

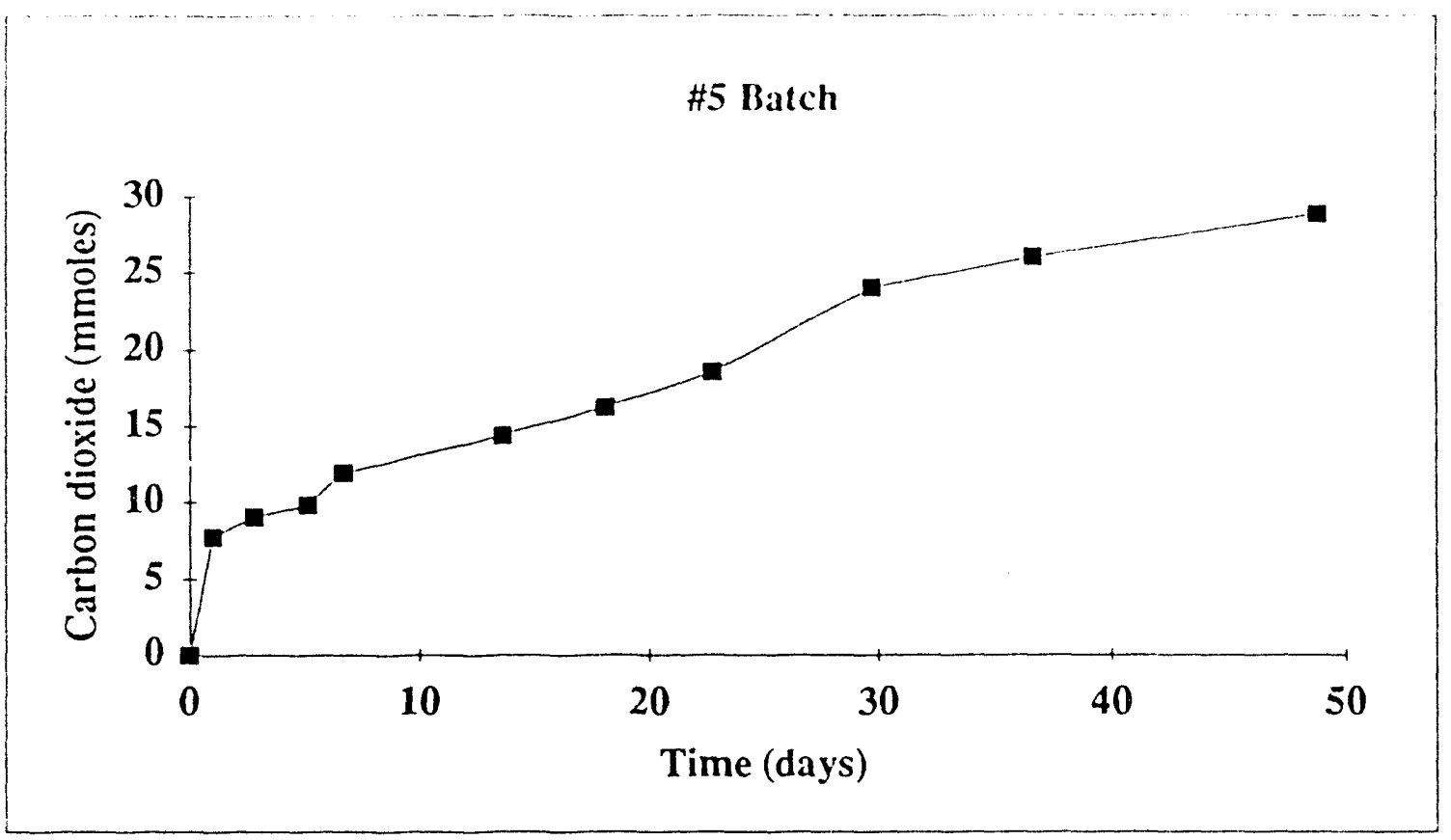

Figure 2. The profile of carbon dioxide production from coal+succinate under batch fermentation conditions without sampling

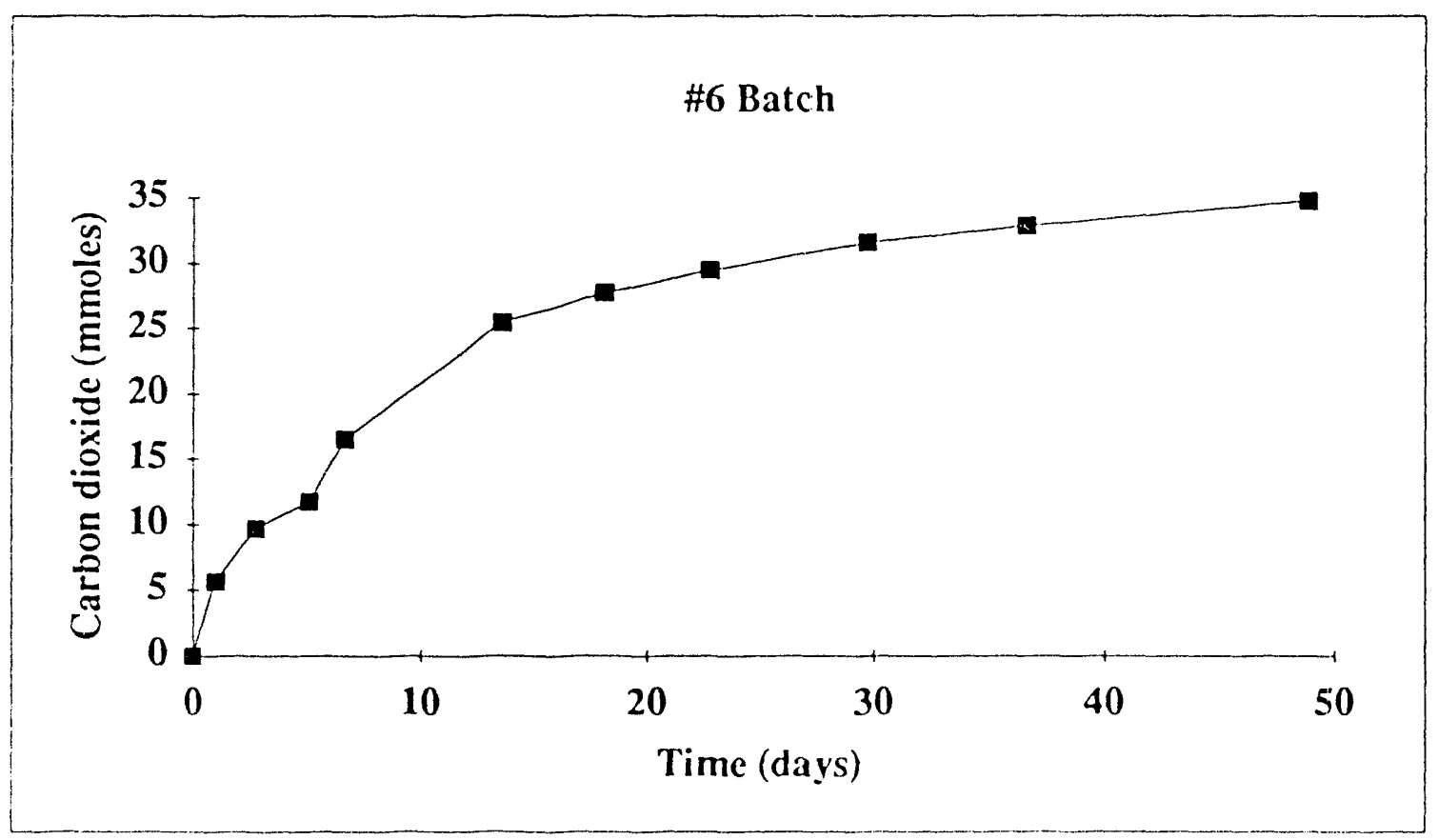


Figure 3. Effect of 2-Bromocthanesulfonic acid (BES) on the gas production from coal in anaerobic tubes

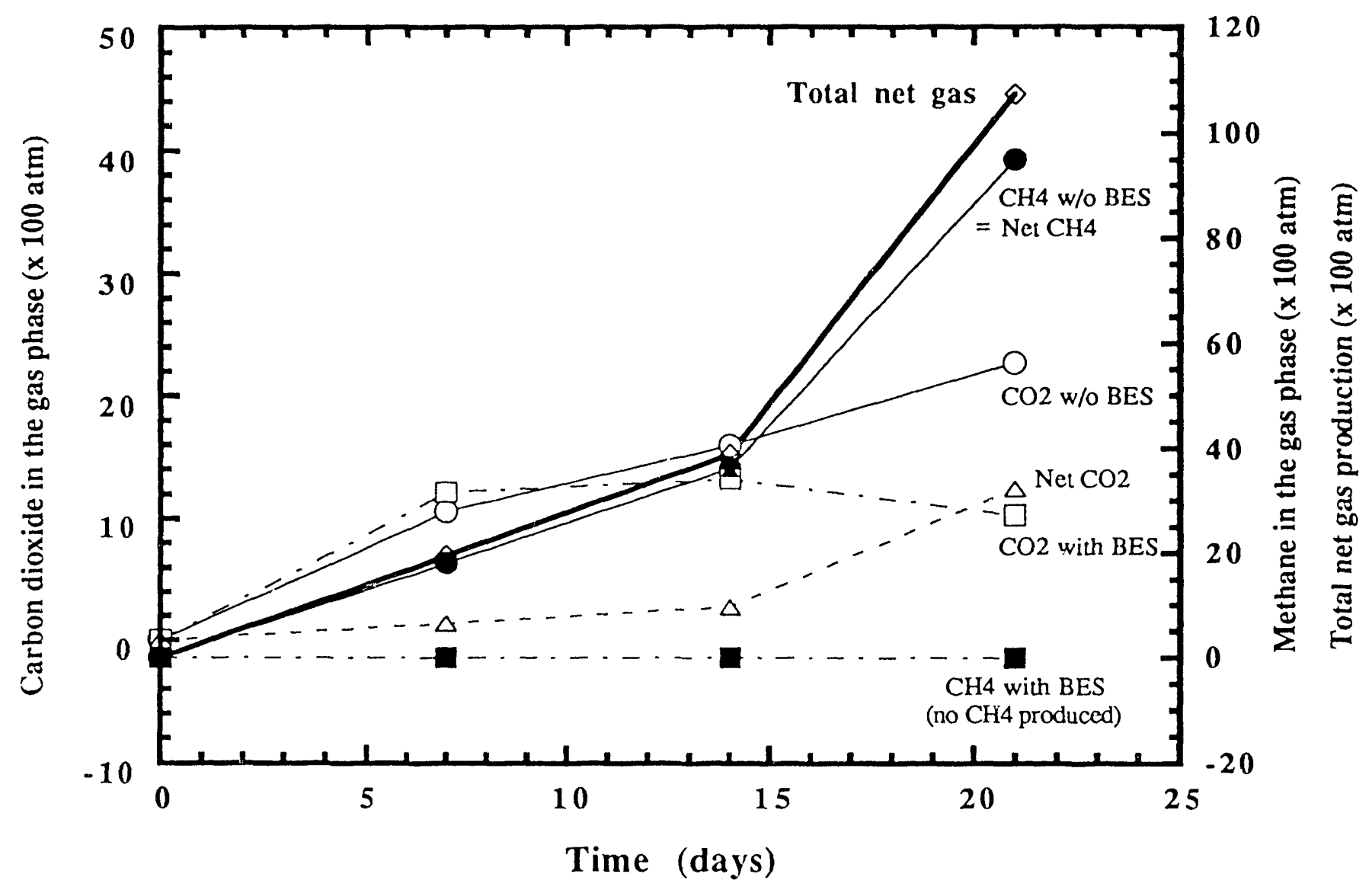


Table 1. Effect of successive subculturing of microbial consortia in medium containing coal on gas production from coal.

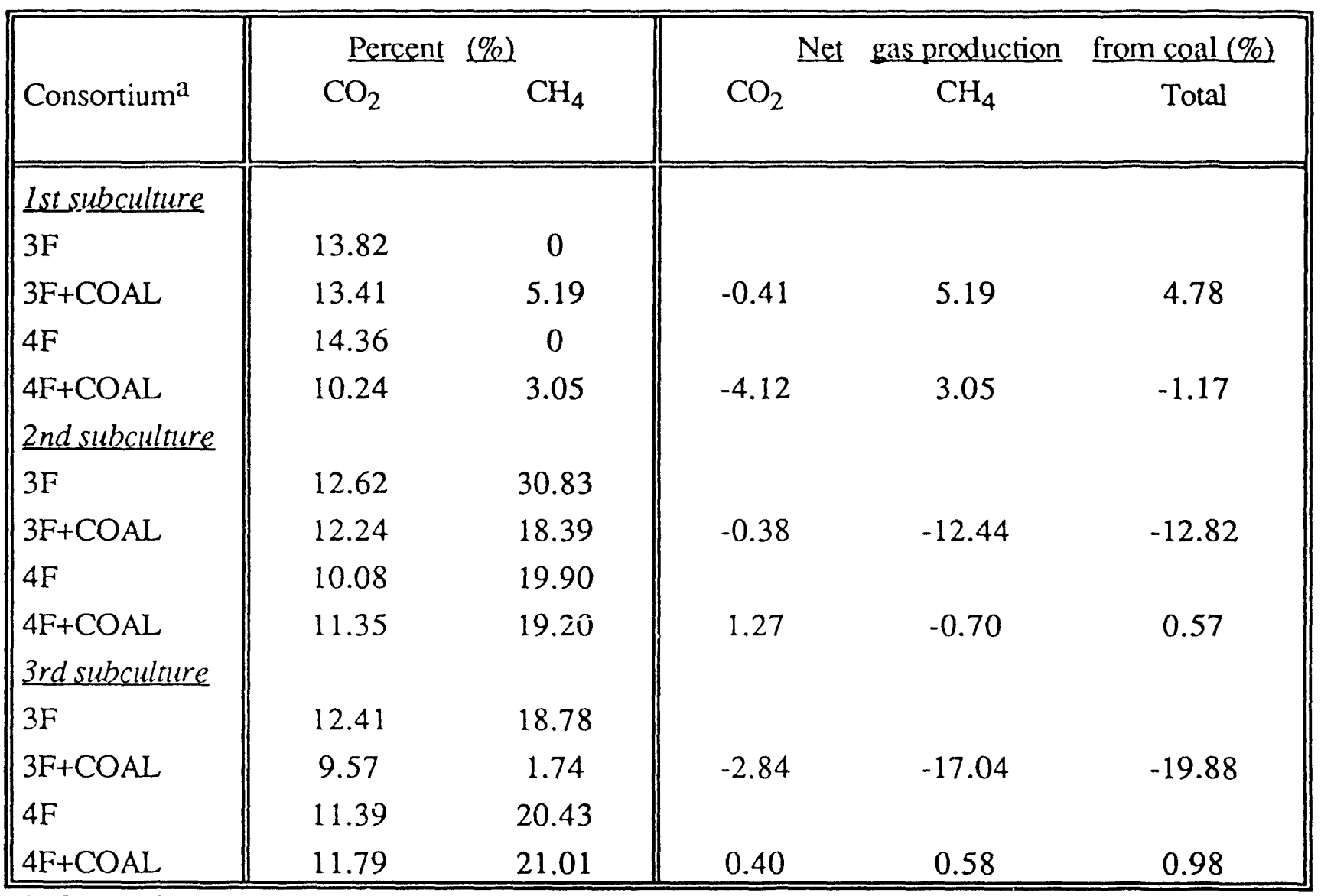

a Consortium $3 \mathrm{~F}$ (from fermentor \#3) was subcultured in medium containing $0.2 \%$ yeast extract plus $5 \%$ coal.

Consortium $4 \mathrm{~F}$ (From fermentor \#4) was in medium containing $0.4 \%$ sodium succinate, $0.2 \%$ yeast extract plus $5 \%$ coal using coal containing cultures as respective inoculum.

Gas production was recorded on day 14. 
Table 2. Net gas production from coal by microbial consortium ( RW $71 \mathrm{C}-4^{\mathrm{a}}$ ) maintained on different carbon sources on day $13 .^{\mathrm{b}}$

\begin{tabular}{|c|c|c|c|c|c|}
\hline $\begin{array}{l}\text { Carbon source } \\
\text { for inoculum }\end{array}$ & $\% \mathrm{CO}_{2}$ & $\% \mathrm{CH}_{4}$ & $\begin{array}{l}\mathrm{Net} \mathrm{CO}_{2} \text { from } \\
\text { Coal }(\%)\end{array}$ & $\begin{array}{l}\mathrm{Net} \mathrm{CH}_{4} \text { from } \\
\mathrm{Coal}(\%)\end{array}$ & $\begin{array}{l}\text { Total net gas } \\
\text { from Coal }(\%)\end{array}$ \\
\hline Acetate & 13.09 & 65.55 & & & \\
\hline Acet+Coal & 14.39 & 66.93 & 1.30 & 1.39 & 2.69 \\
\hline Benzoate & 7.22 & 13.99 & & & \\
\hline $\mathrm{Ben}+\mathrm{Coal}$ & 9.47 & 24.35 & 2.25 & 10.36 & 12.61 \\
\hline Lactate & 17.82 & 39.16 & & & \\
\hline $\mathrm{Lac}+\mathrm{Coal}$ & 19.26 & 42.69 & 1.44 & 3.53 & 4.97 \\
\hline Propionate & 8.30 & 16.65 & & & \\
\hline Prop $\approx$ Coal & 8.68 & 19.66 & 0.38 & 3.01 & 3.39 \\
\hline Succinate & 12.17 & 31.35 & & & \\
\hline $\mathrm{Suc}+\mathrm{Coal}$ & 14.73 & 34.14 & 2.56 & 2.79 & 5.35 \\
\hline Coal (C) & 9.29 & 22.20 & & & \\
\hline $\mathrm{C}+\mathrm{Coal}$ & 5.48 & 13.58 & -3.81 & -8.62 & -12.43 \\
\hline $\mathrm{C}+\mathrm{Suc}$ & 10.09 & 9.10 & & & \\
\hline $\mathrm{C}+\mathrm{Suc}+\mathrm{Coal}$ & 13.58 & 27.32 & 3.49 & 18.22 & 21.70 \\
\hline
\end{tabular}

${ }^{\mathrm{a}} \mathrm{RW} 71 \mathrm{C}-4$ is a fourth transfer of RW71C consortium

${ }^{\mathrm{b}}$ Experimental medium includes $0.2 \%$ yeast extract and $5 \%$ coal with no other $\mathrm{C}$-source. Inoculum was grown in the absence of coal for 3 days in media containing respective $\mathrm{C}$-source $(0.4 \%$, except for sodium acetate $(0.8 \%)$ and coal $(5 \%))$ 
Table 3. Effect of initial $\mathrm{CO}_{2}$ partial pressure on gas production from coal by microbial consortium (RW71).

\begin{tabular}{|c|c|c|c|c|c||}
\hline $\begin{array}{c}\text { Initial } \mathrm{CO}_{2} \\
\text { partial pressure } \\
\text { (atm) }\end{array}$ & $\% \mathrm{CO}_{2}^{\mathrm{a}}$ & $\% \mathrm{CH}_{4}$ & Total gas (\%) & $\begin{array}{c}\text { Net } \mathrm{CO}_{2} \\
\text { change (\%) }\end{array}$ & $\begin{array}{c}\mathrm{Net}^{\mathrm{CH}_{4}} \\
\text { increase (\%) }\end{array}$ \\
\hline \hline 0 (Control) & 16.95 & 34.39 & 51.34 & - & - \\
\hline 0.1 & 14.23 & 30.72 & 44.95 & -16.05 & -10.67 \\
\hline 0.3 & 14.26 & 25.06 & 39.32 & -15.87 & -29.13 \\
\hline
\end{tabular}

a $\mathrm{CO}_{2}$ values were obtained by subtraction of the initial values from the final values.

Experiment was conducted in anaerobic tubes for 14 days

Table 4. Gas production by washed and unwashed coals by anaerobic microbial consortium (RW71)

\begin{tabular}{||c|cc|cc|c||}
\hline \hline \multirow{2}{*}{ Coal sample } & \multicolumn{2}{|c|}{ After 14 days } & \multicolumn{2}{|c||}{ Difference (A - B) } & \multirow{2}{*}{$\begin{array}{c}\text { Total } \\
\text { Difference (\%) }\end{array}$} \\
\cline { 2 - 5 } & $\% \mathrm{CO}_{2}$ & $\% \mathrm{CH}_{4}$ & $\% \mathrm{CO}_{2}$ & $\% \mathrm{CH}_{4}$ & \\
Lignite & & & & - & - \\
Washej (A) & 16.11 & 30.32 & - & 1.32 & 2.67 \\
Unwashed (B) & 14.77 & 29.00 & 1.34 & & \\
Subbituminous & & & & - & - \\
Washed (A) & 17.13 & 42.58 & - & 0.18 & 8.37 \\
Unwashed (B) & 16.95 & 34.39 & 0.18 & & \\
\hline
\end{tabular}


Table 5. Elemental analysis of biotreated coals using a CHN analyzer

\begin{tabular}{|c|c|c|c|c|c|}
\hline Simple & $\mathrm{C}(\%)$ & II (\%) & $\mathrm{N}(\%)$ & $\begin{array}{l}11 / \mathrm{C} \\
\text { ratio }\end{array}$ & $\begin{array}{l}\text { Change in } \mathrm{H} / \mathrm{C} \\
\text { ratio }(\%)\end{array}$ \\
\hline \multicolumn{6}{|l|}{$\begin{array}{l}\text { 1. Biotreated conals from } \\
\text { fermentors }\end{array}$} \\
\hline Control coal & 65.94 & 4.60 & 1.06 & 0.837 & - \\
\hline \#5 fermentor coal & 66.70 & 4.71 & 1.15 & 0.847 & +1.4 \\
\hline \#6 fermentor coal & 66.80 & 4.87 & 1.31 & 0.875 & +4.5 \\
\hline $\begin{array}{l}\text { II. Biotreated coal from tubes } \\
\text { using inoculum grown on }\end{array}$ & & & & & - \\
\hline Acetate & 65.38 & 4.48 & 1.07 & 0.822 & -1.79 \\
\hline Benzoate & 65.29 & 4.54 & 1.20 & 0.834 & -0.36 \\
\hline Lactate & 65.66 & 4.49 & 1.03 & 0.821 & -1.91 \\
\hline Propionate & 65.46 & 4.56 & 1.12 & 0.836 & -0.12 \\
\hline Succinate & 65.53 & 4.61 & 1.13 & 0.844 & +0.84 \\
\hline $\mathrm{Coa}$ ' & 64.11 & 4.50 & 1.18 & 0.842 & +0.60 \\
\hline Coal+Succinate & 64.27 & 4.50 & 1.09 & 0.840 & +0.36 \\
\hline
\end{tabular}

Table 6. Proximal analysis of biotreated coals using a TG analyzer

\begin{tabular}{|c|c|c|c|c|c|c|}
\hline Sample & $\%$ Moisture & $\begin{array}{c}\% \text { Volatile } \\
\text { carbon } \\
\text { (VC) }\end{array}$ & $\begin{array}{c}\text { \% Fixed } \\
\text { carbon } \\
\text { (FC) }\end{array}$ & $\%$ Asn & VC/FC ratio & $\begin{array}{c}\% \text { Change in } \\
\text { VC/FC ratio }\end{array}$ \\
\hline \hline Control coal & 0.54 & 46.60 & 43.18 & 9.677 & 1.0791 & - \\
\hline \#5 fermentor & 4.56 & 47.66 & 38.94 & 8.844 & 1.2239 & +13.42 \\
\hline \#6 fermentor & 4.24 & 45.70 & 41.25 & 8.808 & 1.1079 & +2.67 \\
\hline
\end{tabular}

a Volatile carbon was determined at 17.5 min (elapsed time) under TG analytical conditions. 
Table 7. Net $\mathrm{CO}_{2} / \mathrm{CH}_{4}$ production a by various isolates from coal in the presence of different carbon sources.

\begin{tabular}{||c|cccc||}
\hline Isolate & Coal & $\begin{array}{c}\text { Benzoate } \\
+ \text { Coal }\end{array}$ & $\begin{array}{c}\text { Lactate } \\
+ \text { Coal }\end{array}$ & $\begin{array}{c}\text { Succinate } \\
+ \text { Coal }\end{array}$ \\
\hline After 7 days & & & & \\
\hline $8^{\mathrm{b}}$ & $2.15(9.53)$ & $0.80(3.82)$ & $1.07(-1.06)$ & $2.56(2.40)$ \\
R623 & 0.61 & -0.40 & 0.36 & 0.48 \\
C3 & 1.73 & 0.32 & 0.52 & 3.19 \\
CON & 1.17 & 1.18 & -4.25 & 0.85 \\
A2 & 0.24 & 0.24 & -0.12 & 0.11 \\
& & & & \\
After 28days & & & & $3.09(0.80)$ \\
\hline 8 & $1.00(1.78)$ & $1.33(4.32)$ & $1.56(0.16)$ & 0.87 \\
R623 & 2.13 & -0.79 & 0.58 & 2.84 \\
C3 & 2.13 & -0.16 & 0.44 & 0.31 \\
CON & 0.56 & 0.61 & -0.17 & 0.88 \\
A2 & 0.53 & 0.32 & 0.01 & \\
\hline
\end{tabular}

( ) indicates value of methane

${ }^{\text {a } V a l u e s ~ f r o m ~ r e s p e c t i v e ~ c o n t r o l s ~(o n l y ~ s u p p l e m e n t a l ~ c a r b o n ~ s o u r c e ~ i n ~ t h e ~ a b s e n c e ~ o f ~ c o a l) ~}$ were subtracted

$\mathrm{b}_{\# 8}$ is a microbial consortium containing methanogenic bacteria 

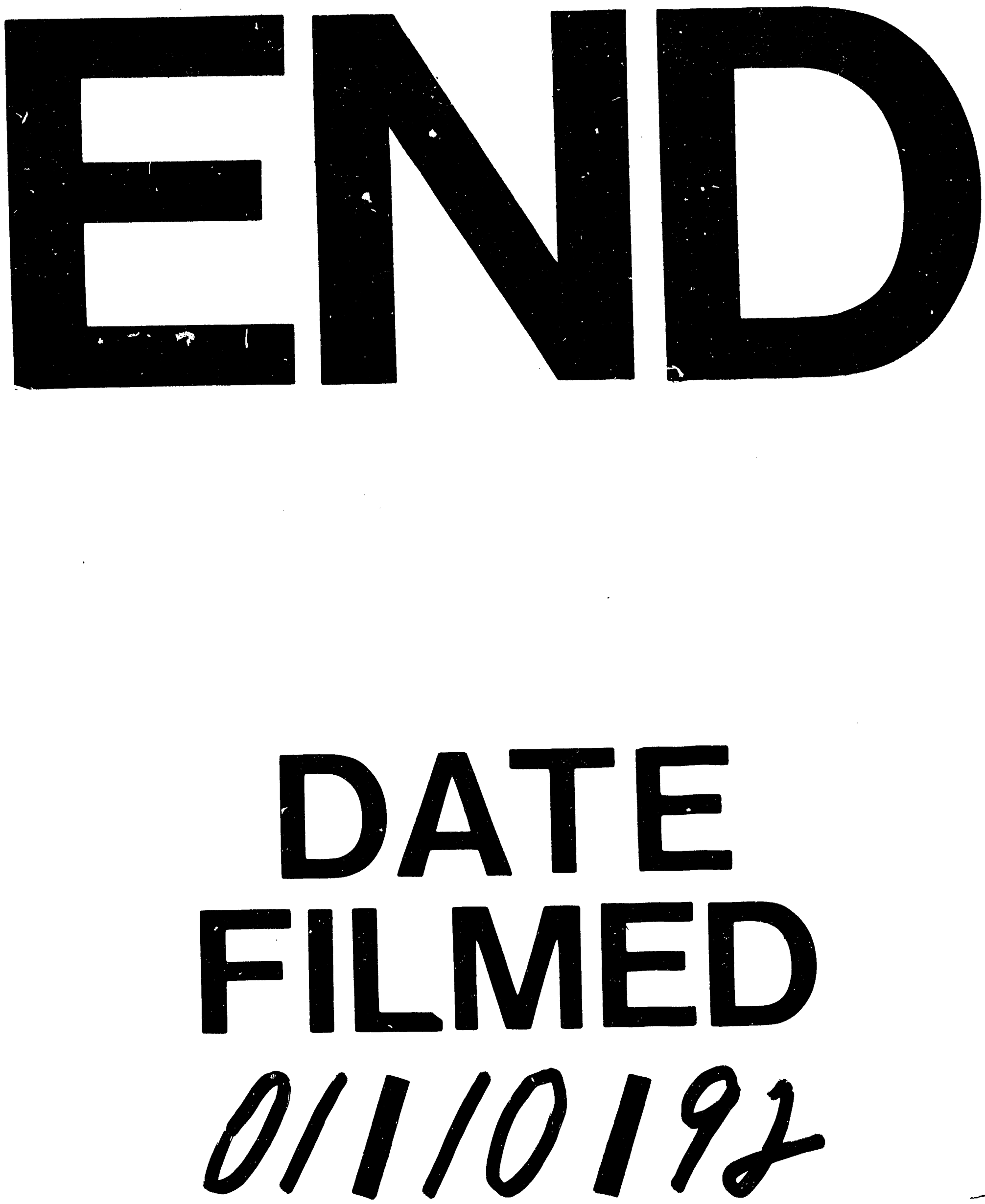